\title{
Wrist fracture management and the role of surgical care practitioner through the patient's
}

\author{
journey
}

\begin{abstract}
The presentation of this case study involves an exploration of the patient's journey in detail after having a traumatic wrist fracture, which is recognised as one of the most common fractures encountered daily in Emergency Services by junior doctors and practitioners. However, this article not only analyses the medical guidance for this type of cases but also, the importance of the surgical care practitioner role in trauma and orthopaedics. All practitioners attending patients in emergency services are required to develop a good knowledge of anatomy, physiology, patient's examination technique, classifications and consequently being aware of the possible surgical options for treatment of the fracture. They will also need to fully understand the legal implications of the consent form to perform a safe practice.
\end{abstract}

Keywords: Wrist, Radius, Fracture, Fixation, Surgical care practitioner

\section{Declaration of ethical approval}

To protect the confidentiality of the patient, the pseudonym "Emma" is used as a pseudonym. This correlates with the Nursing and Midwifery Council (2015) standards of practice. The following case study also respects the confidentiality policy published by the National Health Service of England (2018) to avoid inappropriate disclosure of patients' confidential data.

\section{Introduction of patient's case}

Emma, a 58-year-old female, who works as a catering manager, presented in the emergency department with severe left wrist pain. Sudden joint pain is commonly seen after an acute injury, and patients can have the spontaneous onset of pain without a traumatic event (Shehab and Mirabelli 2013). In this case, Emma reported to the professional taking the history, that her pain started after her hand went through the steering wheel of a golf buggy. Dawson-Bowling et al (2015) stated that the key features during the assessment of the distal forearm are the injury mechanism, age, hand dominance, occupation and medical comorbidities. After a wrist injury, there is a relatively high incidence of distal radius fractures, making them the most common fracture of the upper limb extremity (Egol, Koval and Zuckerman 2010). 


\section{Anatomy}

The anatomy of the wrist includes bones (see Figure 1), ligaments and tendons, muscles (see Figure 2), blood vessels and nerves.

Figure 1: Hand and wrist bones

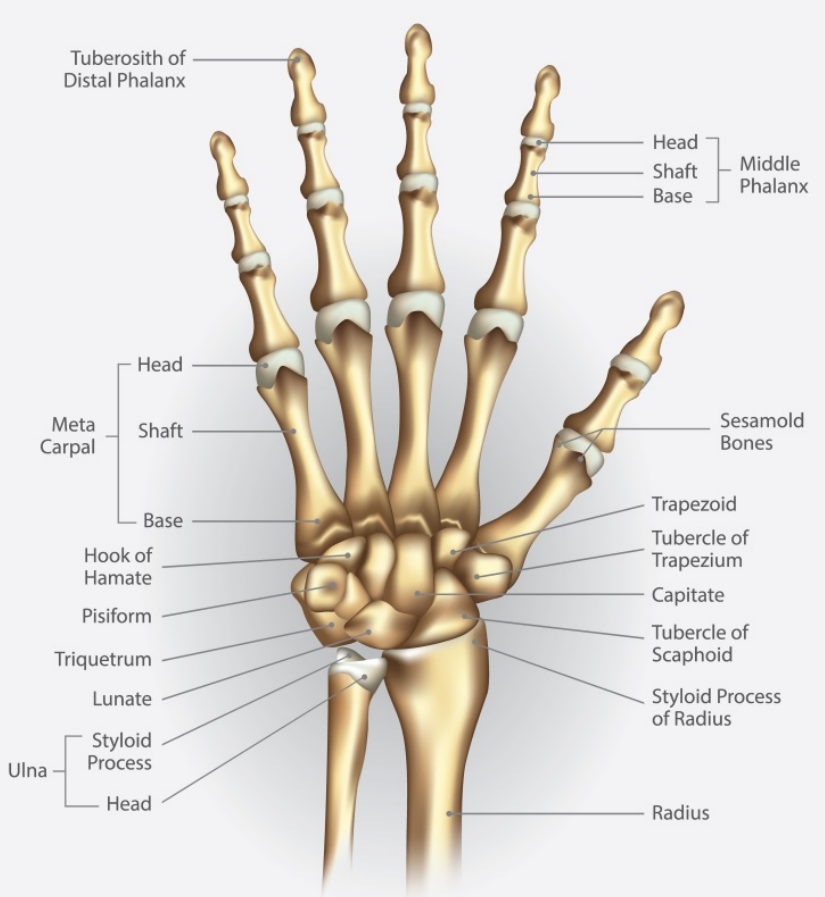

Copyright by: Shutterstock

Figure 2: Superficial muscles of the hand

\section{Muscles of the Hand \\ (right hand, palmar view)}

Superficial

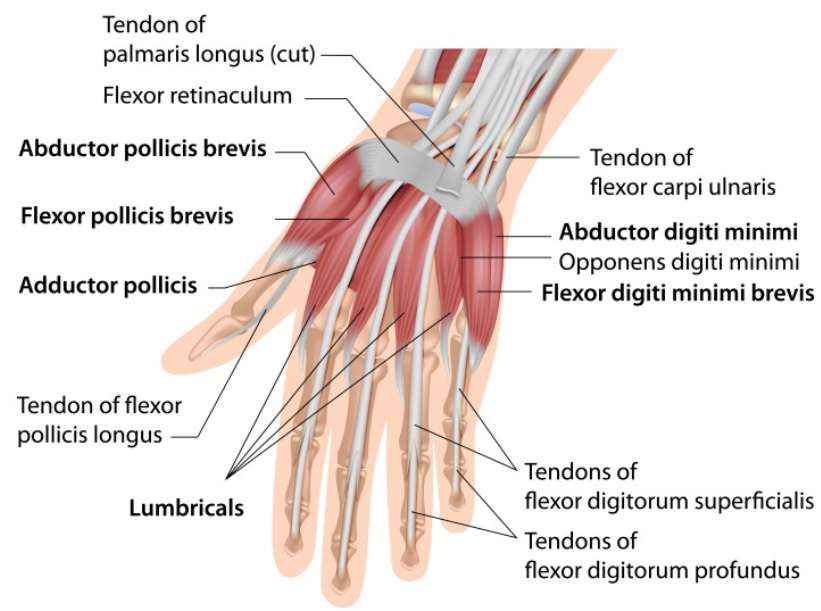

Copyright by: Shutterstock 
This area represents an immense complexity of the wrist movements due to the series of joints involved (Ramachandran and Nunn 2017). The normal anatomy of the wrist includes the connection of the hand with the radius and ulna bones in the forearm (the radio-ulnar joint proximally) (see Figure 3) and distally, the surface of this joint, is formed by the proximal articular surfaces of the scaphoid, lunate and triquetrum (Ellis and Mahadevan 2018). Those individual carpal bones are flexibly interconnected.

\section{Figure 3: Axial view of the wrist}

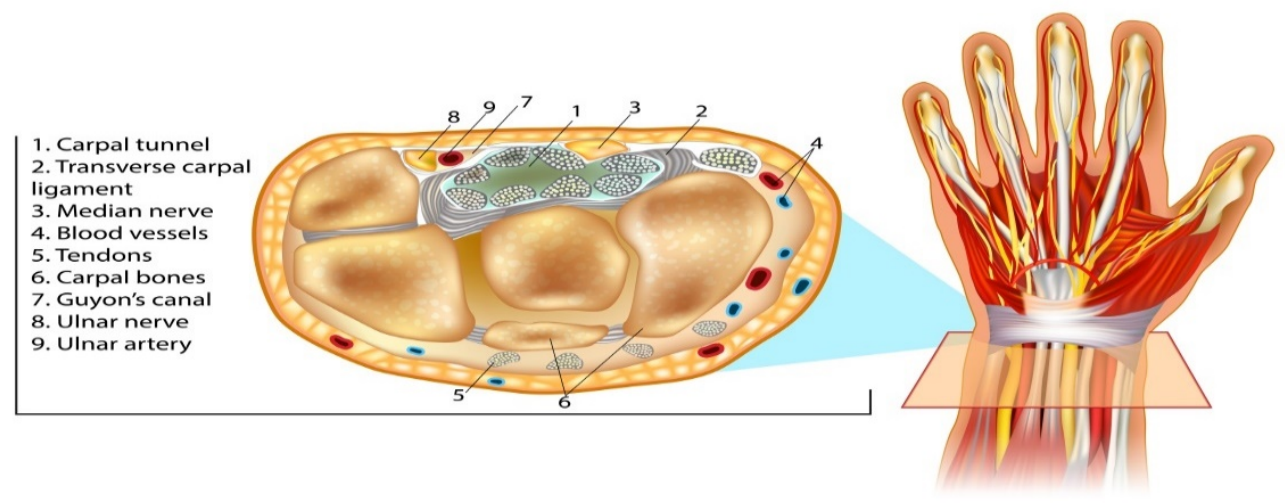

Copyright by: Shutterstock

\section{Aetiology and epidemiology}

There appears to be a consensus in the literature (Egol et al 2010; Meena et al 2014; MacIntyre and Dewan 2016; Wæver et al 2018) regarding the high incidence of distal radius fractures in the upper extremity. The injury mechanism with fractures is mostly caused by a fall on the outstretched hand with the wrist in dorsiflexion (low-energy). The fracture appears when the bone suffers more stress than it can resist (Nelson 2018). According to the mechanism of injury, a distinction should be made between high or low energy fractures in order to have an insight into the aetiology and pathogenesis of the fracture (Dawson-Bowling et al 2015) and its subsequent treatment.

Emma presented with a low-energy traumatic fracture with previous pathological osteopenia. Risk factors such as reduced bone mineral density, female sex, white race, family history and early menopause are known to increase the incidence of radius fractures in this type of injury (Egol et al 2010). Osteoporosis affects the bones by reducing their mass and deteriorating the micro-architecture of bone tissue (Figure 4), as a consequence the bone becomes more fragile and susceptible to low-trauma fractures (Rothrock et al 2015). Folic acid and vitamin B12 have been demonstrated in some cases to reduce the risk of osteoporosis after menopause (Keser et al 2013). However, a recent study published by Garcia Lopez et al (2018) showed no association between those supplements and the risk of fractures; therefore, it should not be prescribed as a fracture prevention measure. In this case, 400 micrograms of folic acid daily were the only tablet that Emma was regularly taking as part of her osteoporosis treatment. 


\section{Figure 4: Stages of osteoporosis}

\section{STAGES OF OSTEOPOROSIS}

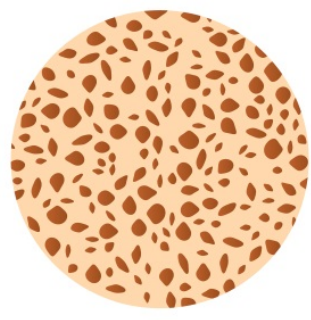

Normal bone

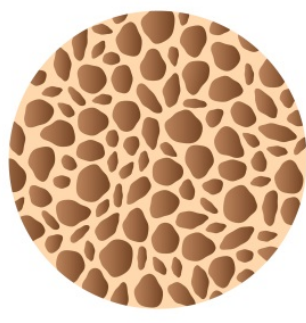

Osteoporosis
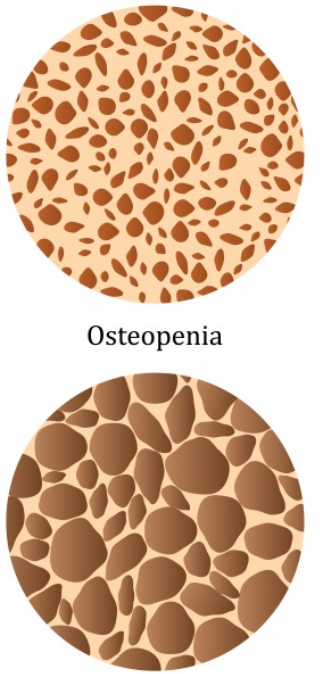

Severe Osteoporosis

Copyright by: Shutterstock

In regards to the selection of appropriate classification of fracture Meena et al (2014) and Shehovych et al (2016) recognised the Orthopaedic Trauma Association (AO/OTA) system to be the most reliable for routine use (see Table 1).

Table 1: The Müller AO Classification of distal radius fracture

\begin{tabular}{|l|l|l|}
\hline \multicolumn{2}{|c|}{23 Distal Radius fracture } \\
\hline 23-A & Extraarticular fracture & 23-A1 ulna fractured, radius intact \\
& 23-A2 radius, simple and impacted \\
& $\begin{array}{l}\text { Partial articular } \\
\text { fracture of the radius }\end{array}$ & 23-A3 radius, multifragmentary \\
& 23-B2 Coronal, dorsal rim \\
& & 23-B3 coronal, palmar rim \\
\hline 23-C & $\begin{array}{l}\text { Complete articular } \\
\text { fracture of the radius }\end{array}$ & 23-C1 articular simple, metaphyseal simple \\
&
\end{tabular}


\begin{tabular}{|l|l|l|}
\hline & 23-C3 articular multifragmentary \\
\hline
\end{tabular}

(Adapted from A.O. Foundation 2019).

Emma's X-ray scan showed: "Impacted fracture of the distal radius with the proximal linear extension of the fracture line; also mildly comminute/spiral fracture of the distal third of the ulna, with dorsal displacement of the distal fracture fragments. Generalised osteopenia".

The aim of fracture management is always based on achieving a pain-free mobile wrist joint with the minimum functional impairment possible (Meena et al 2014). Specific techniques can be used to reach this outcome, depending on the type of fracture. The use of conservative management involves the application of a moulded plaster cast, which is ideal for non-displaced fractures or fractures which can be easily reduced with closed manipulation and with a low tendency to re-displace (Dawson-Bowling et al 2015). However, when surgical fixation is needed, the insertion of Kirschner wires is a possibility only if the patient has good bone quality and enough metaphyseal support (Dawson-Bowling, et al 2015). Otherwise, the surgeon may have to carry out open reduction internal fixation (ORIF), and it is often found to be the most suitable option to achieve the best outcome in unstable fractures (The National Institute for Health and Care Excellence(NICE), 2015). The time recommended for fixation in this type of injury is within 72 hours for intra-articular fractures and within seven days of injury for extraarticular fractures (NICE 2015). In Emma's case, due to the nature and instability of the fracture in plaster and her level of activity, an ORIF was the management chosen by the surgeon. Complications related to the insertion of a volar plating include tendon irritation/rupture (flexor pollicis longus is most commonly affected), injury to the palmar cutaneous branch of the median nerve, loss of reduction/malunion, infection and complex regional pain syndrome (Dawson-Bowling et al 2015).

\section{The rationale for investigations conducted during the consultation}

Emma attended the Emergency department just after her injury, during her admission, she was offered paracetamol and oral morphine to reduce her level of pain. Oral morphine acts in the opioid receptors, which are distributed throughout the central nervous system and within peripheral tissue (Pathan and Williams 2012). Evidence suggests that oral paracetamol works for mild pain; however, in case of severe pain, the pharmacological combination given should be intravenous paracetamol with intravenous morphine (NICE 2015).

As one of the professionals involved in the patient pathway, the surgical care practitioner supports on-call doctors and emergency services (The Royal College of Surgeons $2014 ;$ 2018). To avoid mismanagement, a detailed history was taken by the Surgical Care Practitioner (SCP), including symptoms, psychological, spiritual, social and cultural factors (The Royal College of Surgeons, 2014) and helped the professional to conduct a more thorough physical examination and request the necessary radiological investigations.

After ruling out any other lesions, special attention was given to the injury site. In this case, the patient's history of trauma guided the professional SCP to the examination of the forearm and wrist, looking for clinical signs of fracture as recommended by Innes et al (2018). Alternatively, the diagnosis was based on the different sign and symptoms 
encountered during the examination and the further request scans. In this case, the possible differential diagnoses were wrist strain, ligamentous carpal injury, triangular fibrocartilage complex tear (see Table 2) or wrist fracture.

Table 2: Differential diagnosis of wrist fracture

\begin{tabular}{|c|c|c|}
\hline Disease/condition & Differentiating signs/Symptoms & Differentiating tests \\
\hline Wrist strain & O No presentation of deformity & $\begin{array}{l}\text { Radiographs: no } \\
\text { fracture }\end{array}$ \\
\hline $\begin{array}{l}\text { Ligamentous } \\
\text { carpal injury }\end{array}$ & $\begin{array}{l}\text { Wrist pain with no signs of } \\
\text { fracture } \\
\circ \text { Pain with palpation on } \\
\text { dorsum of wrist at the } \\
\text { scapholunate interval } \\
\circ \text { Positive Watson shift test }\end{array}$ & \\
\hline $\begin{array}{l}\text { Triangular } \\
\text { fibrocartilage } \\
\text { complex (TFCC) } \\
\text { tear }\end{array}$ & $\begin{array}{ll}\circ & \text { Ulnar-sided wrist pain } \\
\circ & \text { Pain with more ulnar } \\
\text { deviation than radial. } \\
\circ \text { Pain with manipulation of } \\
\text { distal ulna dorsal/volar }\end{array}$ & $\begin{array}{l}\text { For accurate diagnosis: } \\
\qquad \begin{aligned} & \text { MRI arthrogram } \\
& \text { of the wrist } \\
& \circ \text { Wrist arthroscopy }\end{aligned}\end{array}$ \\
\hline
\end{tabular}

(Adapted from Schep ,2020).

To develop an appropriate structure of the examination process, Burnand and Browse (2015) supported by Innes, Dover and Fairhurst (2018) divided it into inspection, palpation and movement of the joint. The professional should have the patient's consent before performing any examination or investigation (General Medical Council 2013). During the inspection of the forearm swelling, bruising and some deformity of the wrist were seen. Specific characteristics as angulation, rotation, displacement and shortening of the joint should be recorded clearly into the patient's notes. Also, there was evidence of soft tissue swelling, which was classified using the Tscherne classification for closed fractures, but there was no evidence of a compound wound (Burnand and Browse 2015). Palpation of the wrist showed generalised tenderness. This is a clinical sign of fracture. Finally, the joint was assessed on movement (see Table 3 ) very carefully as it could be painful for the patient. It is important not to encourage any abnormal movement, as this may cause further soft tissue damage or periosteal stripping (Burnand and Browse 2015).

Table 3: Normal movements of the condyloid synovial wrist joint

\begin{tabular}{|l|l|}
\hline Flexion & Bending the palm toward the forearm \\
\hline Extension & Moving the hand toward the thumb \\
\hline
\end{tabular}




\begin{tabular}{|l|l|}
\hline Radial deviation & Moving the hand toward the thumb \\
\hline Ulnar deviation & Moving the hand toward the little finger \\
\hline Circumduction & Combination of extension and flexion with radial and ulnar deviation \\
\hline
\end{tabular}

(Adapted from Hirt et al $2017: 11$ ).

Eyler et al (2018) suggested after studying 232 patients presented to the Emergency Department with acute wrist trauma that the trilogy of wrist oedema, deformity and pain with pronation is a reliable clinical prediction of all wrist fractures, $94 \%$ of sensitive and 95\% specific. Further assessment should also include feeling the peripheral pulses (including the capillary refill time for the skin circulation) and examining the peripheral nerves. In cases of the suspected limb or joint fracture, the examination must include the patient's neurovascular status to exclude compartment syndrome or any damage to the nerves. The incidence of neurological impairment on admission was reported by Marcheix et al (2016) to be $9 \%$ just after forearm fracture.

Due to the practitioner's suspicions of a fracture, radiographs were requested. Radiographic evaluation through a plain $\mathrm{x}$-ray is essential for further classification, treatment and follow up of wrist fractures. This should include a posteroanterior view (of the full forearm and wrist) and a right lateral radiograph (Dawson-Bowling et al 2015). Other radiographic images as Computed Tomography could be useful for confirmation of occult fractures if there were any suspicion of this during the patient examination.

Preoperative evaluation should be done in advance, often one or more days before the procedure. The patient should be aware of the possible risks of the anaesthesia in addition to the surgical ones when discussing the non-conservative treatment. Those could be present even in healthy patients. An appropriate classification system was developed by the American Society of Anaesthesiologist (ASA) to provide uniform guidelines. This classification is based on the physiological dysfunction and the anatomic abnormalities of the patient preoperatively (Rothrock, McEwen and Alexander 2015). Following the guideline for a 58-year-old female with a history of osteoporosis having an open reduction and internal fixation of her wrist (intermediate surgery complexity), ASA II (mild systemic disease) was assigned to the patient (see Table 4).

Table 4: Preoperative tests for ASA II

\begin{tabular}{|l|l|}
\hline \multicolumn{2}{|c|}{ Preoperative tests for ASA II } \\
\hline Renal function & If there is a risk of acute kidney injury. \\
\hline Electrocardiogram & For patients with cardiovascular, renal or diabetes comorbidities. \\
\hline Full Blood count & $\begin{array}{l}\text { Useful for the diagnosis of additional pathologies that the patient } \\
\text { may present with; for example, the white cell count is usually }\end{array}$ \\
\hline
\end{tabular}




\begin{tabular}{|l|l|}
\hline & $\begin{array}{l}\text { raised in infection and red cell count and haemoglobin low in } \\
\text { anaemia. }\end{array}$ \\
\hline Biochemistry & $\begin{array}{l}\text { Generally used to review electrolytes, renal function and } \\
\text { inflammatory markers such as C-reactive protein. }\end{array}$ \\
\hline Clotting screen & $\begin{array}{l}\text { In patients on anticoagulation medication and also sometimes to } \\
\text { assess the risk of venous thromboembolism (VTE). }\end{array}$ \\
\hline
\end{tabular}

(Adapted from sources: Basten 2013; National Health Service of England 2018).

\section{Ethical principles and preoperative consent}

The term medical ethics describes the use of ethical reasoning when a medical decision is required (Herring 2018). It guides the clinician to resolve ethical issues in different situations (Davey et al 2017). Specifically, principlism is still considered to be the most well-recognised approach in bioethics with the influence of Beauchamp and Childress work: "Principles of Biomedical Ethics" (Herring 2018). Respect for autonomy, nonmaleficence, beneficence and justice are the four principles in which principlism is built representing a "common morality" in many societies (Beauchamp and Childress 2013). Those premises could be transferred to the preoperative consent, which is a process that involves clinicians working in partnership with patients to support their decisionmaking. To achieve it, clinicians should fully inform and discuss with the person receiving the treatment about their condition and possible options in a way that they can understand (General Medical Council 2008; The Royal College of Surgeons 2016). The bioethical principle of autonomy should be reflected in every patient's consent process, promoting the legal aspect to decide what happens to them and allowing them to make voluntary choices (Entwistle et al 2010).

The SCP's framework was developed by The Royal College of Surgeons in 2006 (further updated in 2014) being the main reference document for the establishment of standards during training (RCS, 2020). SCP role description contains the possibility for these professionals to consent to patients preoperatively. This may occur when the surgeon delegates responsibility agreeing that the SCP has developed the appropriate knowledge to safely do so (The Royal College of Surgeons 2014).

To accomplish all the ethical and legal requirements, the SCP must follow the General Medical Council (GMC) guidelines for Good Medical Practice and their local trust policy surrounding the consenting process (RCS 2014). Also, professionals consenting patients are required to acknowledge the principles of the Mental Capacity Act (2005), this will guide them to establish if the patients can apply their legal right to consent effectively (RCS 2014).

The SCP role helps to improve the continuity of care and patient experience by having an extensive area of practice through the whole perioperative journey (RCS 2018). It may involve the clinical assessment of patients in Emergency Departments, surgical preparation on admission, intra-operative assistance to the surgeon, postoperative 
revision of patients allocated on the wards, managing clinics and also, in some occasions acting as trauma coordinator for the department.

\section{Effective teamwork in perioperative care}

In this case, the patient was correctly positioned in the operating table and also adequate communication techniques were followed to complete the safety checklist. The SCP helped the surgeon to perform safe access to the fractured bone by knowing the anatomical layers and structures of the forearm (Hall et al 2016). During the procedure, this professional assisted in handling the tissues appropriately (Myint and Kirk 2018), carefully collaborating with the surgeon to diminish the potential damage to the median nerve, radial artery or volar wrist capsule ligaments (Taylor and Sharareh 2019). Finally, after distal radial fixation was achieved (see Figure 5), the SCP closed the different anatomical layers ensuring a good eversion of the skin edges to facilitate wound healing (Myint and Kirk 2018).

The SCPs' area of practice is based in the intra- and perioperative environment, including patients from elective or emergency departments. This professional as part of the surgical team should be familiar with the national and local safety standards through "The National Safety Standards for Invasive Procedures" (NatSSIPs) and "Local Safety Standards for Invasive Procedures" (LocSSIPs) (National Health Service of England 2015). The NatSSIPs describes standards required to deliver safe care for patients undergoing an invasive procedure, highlighting the importance of the teamwork as the baseline to achieve it during the procedural pathway. As a consequence, the documentation and data collection through the usage of audits for outcome and compliance then became necessary to measure the standards of care provided (National Health Service of England 2015).

After the appropriate dressing was applied and the bone fixation protected using a below elbow plaster of Paris (Dawson-Bowling et al 2015), Emma was transferred to the recovery room for management of complications and pain control (Rothrock McEwen and Alexander 2015). The SCP actively helps with the identification of surgical problems, including the assessment of the wound and the patient's initial treatment (RCS 2018). Special consideration was given to maintain the patient's vital signs, temperature, adequate respiratory rate and depth and laboratory values within normal ranges. Also, early ambulation is considered essential to speed recovery and for prevention of further complications (Rothrock McEwen and Alexander 2015). Emma's neurovascular observations were regularly checked to detect early stages of possible compartment syndrome or neurovascular damage (Dawson-Bowling et al 2015).

Figure 5: A.P. and lateral images of volar locked plating technique 


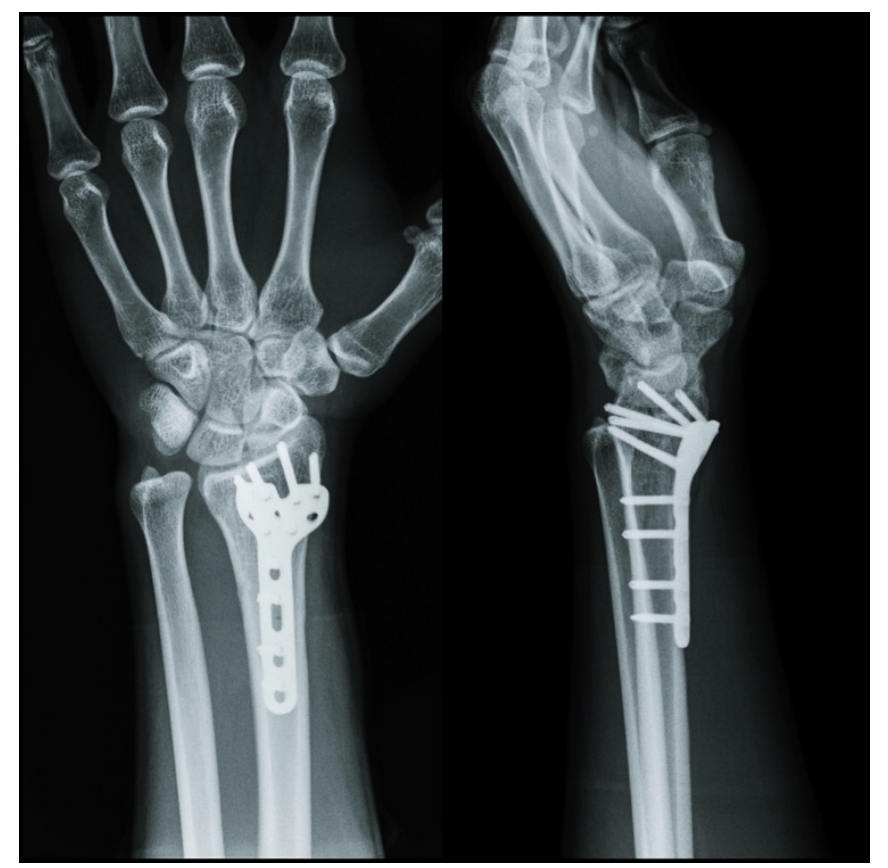

Copyright by: Shutterstock

\section{Conclusion}

The analysis of the patient's medical condition and the outcome of actual operation itself was found highly important to improve the understanding of possible problems and to develop a care plan for discharge. The discharge summary recorded all the necessary instructions after the operation including Emma's follow up planned for two weeks post-surgery, and the SCP felt it was imperative to explain to the patient the possible problems which may occur with the splint and the warning signs to watch out for. Those could be related to numbness, tingling pain or pins and needles. Emma was given a postoperative information leaflet, and she was advised to attend ED if any of those signs appeared.

\section{Conflict of Interest: None}

Acknowledgement: Susan Hall for her support and guidance.

\section{References}

A.O. Foundation, 2019. Distal forearm. [Image online] Available at: $<$ https://www2.aofoundation.org/wps/portal/surgery?showPage=diagnosis\&bon

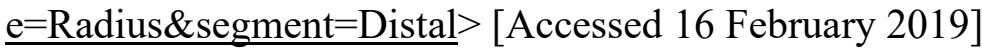

Basten, G., 2013. Blood Results in Clinical Practice. [e-book] United Kingdom: M\&K Update Ltd. Available through: $<$ https://libweb.anglia.ac.uk/ $>$ [Accessed 20 March 2019] 
Beauchamp, T.L. and Childress, J. F., 2013. Principles of biomedical ethics. $7^{\text {th }}$ ed. New York : Oxford University Press.

British Medical Journal, 2018. Wrist fractures: differential diagnosis. [online] Available at: $\quad<$ https://online.epocrates.com/diseases/39235/Wrist-fractures/DifferentialDiagnosis $>$ [Accessed 3 March 2019]

Burnand, K.G. and Browse, N. L., 2015. Browse's introduction to the symptoms and signs of surgical disease. $5^{\text {th }}$ ed. [e-book] Boca Raton, Florida : CRC Press. Available through: $<$ https://libweb.anglia.ac.uk/ $>$ [Accessed 22 February 2019].

Davey, P., Rathmell, A., Dunn, Michael, Foster, C. and Salisbury, H., 2017. Medical Ethics, Law and Communication at a Glance. Oxford: Wiley Backwell

Dawson-Bowling, S., Achan, P., Briggs, T. and Ramachandran, M., 2015. Orthopaedic Trauma: The Stanmore and Royal London Guide. Boca raton, Florida: CRC Press.

Egol, K.A., Koval, Kenneth, J. and Zuckerman, J. D., 2010. Handbook of fractures. $4^{\text {th }}$ ed. [e-book] Philadelphia, Pa.; London : Wolters Kluwer/Lippincott Williams \& Wilkins. Available through: Anglia Ruskin University Library website

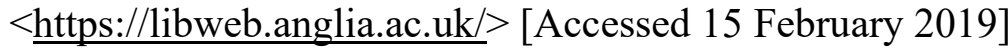

Ellis, H. and Mahadevan, V., 2018. Clinical anatomy : applied anatomy for students and junior doctors. 14 ${ }^{\text {th }}$ ed. [e-book] Hoboken, NJ : Wiley Blackwell. Available through: Anglia Ruskin University Library website $<\underline{\text { https://libweb.anglia.ac.uk } />}$ [Accessed 15 February 2019]

Entwistle, V., Carter, S., Cribb, A. and McCaffery, K., 2010. Supporting Patient Autonomy: The Importance of Clinician-patient Relationships. Journal of General Internal Medicine, [e-journal] 25 (7), pp.741-745. http://dx.doi.org/10.1007/s11606-010-1292-2.

Eyler, Y., Sever, M., Turgut, A., Yalcin, N., Zafer, N., Suner, A., Aksay, E. and Yesilaras, M., 2018. The evaluation of the sensitivity and specificity of wrist examination findings for predicting fractures. American Journal of Emergency Medicine, [e-journal] 36 (3), pp.425-429.

http://dx.doi.org/10.1016/j.ajem.2017.08.050.

Garcia Lopez, M., Baron, J.A., Omsland, T.K., Søgaard, A.J. and Meyer, H.E., 2018. Homocysteine-Lowering Treatment and the Risk of Fracture: Secondary Analysis of a Randomized Controlled Trial and an Updated Meta-Analysis. JBMR Plus, [e-journal] 2 (5), pp.295-303. Available through: $<$ https://libweb.anglia.ac.uk/> [Accessed 10 April 2019]

General Medical Council, 2008. Consent: patients and doctors making decisions together. [online] Available at: <https://www.gmc-uk.org/ethicalguidance/ethical-guidance-for-doctors/consent> [Accessed 17 February 2019]

General Medical Council (GMC), 2013. Good Medical Practice. [pdf] Available at: $<\underline{\text { https://www.gmc-uk.org/ }}$ /media/documents/Good medical_practice English_1215.pdf_51527435.pdf $>$ [Accessed 17 February 2019] 
General Medical Council (GMC), 2013. Personal beliefs and medical practice. [pdf] Available at: < $\quad$ https://www.gmc-uk.org//media/documents/Personal beliefs and medical practice.pdf 58833376.pdf $>$ [Accessed 17 February 2019]

General Medical Council (GMC), 2017. Keeping records. [online] Available at: $<$ https://www.gmc-uk.org/ethical-guidance/ethical-guidance-fordoctors/protecting-children-and-young-people/keeping-records $>$ [Accessed 17 February 2019]

Government of England, 2005. Mental Capacity Act. [online] Available at: $<$ www.legislation.gov.uk/ukpga/2005/9/contents $>$ [Accessed 17 February 2019]

Hall, S., Quick, J. and Hall, A., 2016. The Perfect Surgical Assistant: Calm, Confident, Competent and Courageous. Journal of Perioperative Practice, [e-journal] 26 (9), pp.201-204. Available at: $<$ https://www.ncbi.nlm.nih.gov/pubmed/29328813 $>$ [Accessed 21 March 2019].

Herring, J., 2018. Medical law and ethics. $7^{\text {th }}$ ed. Oxford: Oxford University Press.

Hirt, B., Seyhan, H., Wagner, M. and Zumhasch, R., 2017. Hand and Wrist Anatomy and Biomechanics: A Comprehensive Guide. [e-book] Stuttgard, Germany: Thieme Medical Publishers. Available through: < $\underline{\text { https://libweb.anglia.ac.uk/ }>}$ [Accessed 3 March 2019]

Innes, J.A., Dover, A.R. and Fairhurst, K., 2018. Macleod's clinical examination. $14^{\text {th }}$ ed. Amsterdam : Elsevier.

Keser, I., Ilich, J.Z., Vrkić, N., Giljević, Z. and Colić Barić, I., 2013. Folic acid and vitamin B12 supplementation lowers plasma homocysteine but has no effect on serum bone turnover markers in elderly women: a randomised, double-blind, placebo-controlled trial. Nutrition Research, [e-journal] 33 (3), pp.211-219.

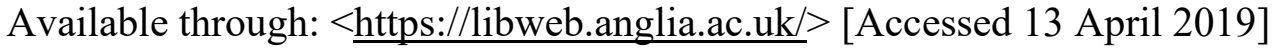

Leventhal, H., Phillips, L. and Burns, E., 2016. The Common-Sense Model of SelfRegulation (CSM): a dynamic framework for understanding illness selfmanagement. Journal of Behavioral Medicine, [e-journal] 39 (6), pp.935-946. http://dx.doi.org/10.1007/s10865-016-9782-2.

Macintyre, N.J. and Dewan, N., 2016. Epidemiology of distal radius fractures and factors predicting risk and prognosis. Journal of Hand Therapy, [e-journal] 29 (2), pp.136-145.

http://dx.doi.org/10.1016/j.jht.2016.03.003.

Marcheix, P., Delclaux, S., Ehlinger, M., Scheibling, B., Dalmay, F., Hardy, J., Lebaron, M. and Bonnevialle, P., 2016. Pre- and postoperative complications of adult forearm fractures treated with plate fixation. Orthopaedics \& Traumatology: Surgery \& Research, [e-journal] 102 (6), pp.781-784. http://dx.doi.org/10.1016/j.otsr.2016.04.014.

Meena, S., Sharma, P., Sambharia, A. and Dawar, A., 2014. Fractures of distal radius: An overview. Journal of Family Medicine and Primary Care, [e-journal] 3 (4) pp.325. http://dx.doi.org/10.4103/2249-4863.148101. 
Meyer, D., Leventhal, H. and Gutmann, M., 1985. Common-Sense Models of Illness: The Example of Hypertension. Health Psychology, [e-journal] 4 (2), pp.115-135.

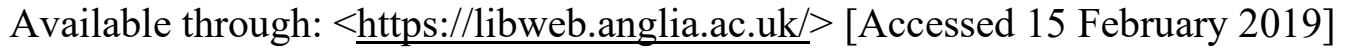

Myint, F. and Kirk, R. M., 2018. Kirk's basic surgical techniques. $7^{\text {th }}$ ed. Amsterdam : Elsevier

National Health Service of England, 2018. Examples: blood test. [online] Available at: $<$ https://www.nhs.uk/conditions/blood-tests/types/ $>$ [Accessed 20 February 2019]

National Health Service of England, 2018. Confidentiality policy. [online] Available at: $<$ https://www.england.nhs.uk/wp-content/uploads/2016/12/confidentialitypolicy-v4.pdf $>$ [Accessed 26 February 2019]

National Institute for Health and Care Excellence (NICE), 2015. Fractures (noncomplex): assessment and management. [pdf] Available at:

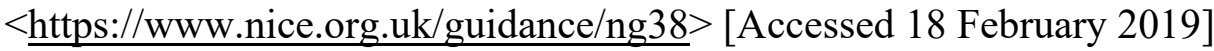

National Institute for Health and Care Excellence (NICE), 2018. Preoperative test overview. [pdf] Available at: $<$ https://pathways.nice.org.uk/pathways/preoperative-tests $>$ [Accessed 18 February 2019]

National Institute for Health and Care Excellence (NICE), 2019. Limb and joint fractures in hospital. [pdf] Available at: $<$ https://pathways.nice.org.uk/pathways/trauma\#path=view\%3A/pathways/traum a/limb-and-joint-fractures-in-hospital.xml\&content=view-index $>$ [Accessed 18 February 2019]

Nelson, D.L., 2018. Distal radius fractures. [online] Available at: $<\underline{\text { https://emedicine.medscape.com/article/1245884-overview\#a4 }>\text { [Accessed: }}$ 23/05/2019]

Nursing and Midwifery Council, 2015. The Code: Professional standards of practice and behaviour for nurses and midwives. [online] Available at: $<$ https://www.nmc.org.uk/standards/code/ $>$ [Accessed 26 February 2019]

Pathan, H. and Williams, J., 2012. Basic opioid pharmacology: an update. British Journal of Pain, [e-journal] 6 (1), pp.11-16. http://dx.doi.org/10.1177/2049463712438493.

Ramachandran, M. and Nunn, T., 2017. Basic orthopaedic sciences : the Stanmore guide. $2^{\text {nd }}$ edition ed. Boca Raton : CRC Press.

Rothrock, J.C., McEwen, D.R. and Alexander, E.L., 2015. Alexander's care of the patient in surgery. $15^{\text {th }}$ ed. [e-book] St. Louis, Missouri : Elsevier. Available

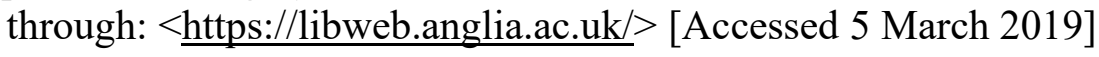

Schep,N. W.L, 2020. Wrist fractures. BMJ Best Practice. [Online] Available from: https://bestpractice.bmj.com/topics/en-us/392 [Accessed 12 October 2020]

Shehab, R. and Mirabelli, M.H., 2013. Evaluation and Diagnosis of Wrist Pain: A CaseBased Approach. American Family Physician, [e-journal] 87 (8), pp.568-573. $<$ https://www.aafp.org/afp/2013/0415/p568.html $>$ [Accessed 28 February 2019] 
Shehovych, A., Salar, O., Meyer, C. and Ford, D.J., 2016. Adult distal radius fractures classification systems: essential clinical knowledge or abstract memory testing? Annals of The Royal College of Surgeons of England, [e-journal] 98(8), pp.525531.

http://dx.doi.org/10.1308/rcsann.2016.0237.

Taylor, B. and Sharareh, B., 2019. FCR approach to distal radius. [online] Available at: $<$ https://www.orthobullets.com/approaches/12071/fcr-approach-to-distal-radius $>$

[Accessed 12 May 2020]

The Royal College of Surgeons of England (RCS), 2014. The good surgical practice. [pdf] Available at: <https://www.rcseng.ac.uk/standards-and-research/gsp/> [Accessed 26 February 2019]

The Royal College of Surgeons of England (RCS), 2016. Consent: Supported decision making- a good practice guide. [pdf] Available at: $<$ https://www.rcseng.ac.uk/library-and-publications/rcspublications/docs/consent-good-practice-guide/> [Accessed 10 April 2019]

The Royal College of Surgeons of England (RCS), 2018. Consent. [online] Available at: $<$ https://www.rcseng.ac.uk/standards-and-research/gsp/domain-3/3-5-1-consent/> [Accessed 26 February 2019]

The Royal College of Surgeons of England (RCS), 2018. Surgical Care Team guidance framework. [pdf] Available at: <https://www.rcseng.ac.uk/standards-andresearch/standards-and-guidance/service-standards/surgical-care-team-guidance/> [Accessed 26 February 2019]

The Royal College of Surgeons of England (RCS), 2020. Surgical Care Practitioner Programmes. [online] Available at: $<$ https://www.rcseng.ac.uk/education-andexams/accreditation/surgical-care-practitioner/> [Accessed 25 May 2020]

Wæver, D., Madsen, M.L., Rölfing, J.,Hendrik Duedal, Borris, L.C., Henriksen, M., Nagel, L.L. and Thorninger, R., 2018. Distal radius fractures are difficult to classify. Injury, [e-journal] 49, pp.S32.

http://dx.doi.org/10.1016/S0020-1383(18)30299-7. 